\title{
The Marital Assets Issues in Albanian Legislation
}

\author{
Mimoza Mehilli \\ PhD Candidate at the European University of Tirana \\ Email:mehilli.mimoza@gmail.com
}

Doi:10.5901/ajis.2016.v5n3s1p309

\begin{abstract}
The right to marital assets is a right of future spouses, known from all the international legislations in variuos forms. In Albania, the marital assets is based on family rights forseen in the Code of French and Italian families. The marital assets treats the regulation of the common marital assest of spouses. The decision of having marital assets has evolutionalized from the begining of the family to nowdays. In the private international right this takes part as the family right. These assets are forseen in a prenuptial agreement in the moment the marriage happens, and after the event is not related to children, their treatment or care, but it is related only to the spouses and the way theirs assets are administered. In Albania the prenuptial agreement is seen initially in the Family Code of 2003, but its implementation is still not done as a result among others of albanian mentality. In albanian marriages there is not a prenuptial agreement which treats the premarriage asstes of each spouse before marriage. The changes this institution is developed in Albania from the countries the legislation is based, are still large. Through the analyses of the legislation and its implementation in the cases of divorce, this study gives a clear view of the importance of having a prenuptial ageement before marriage takes place.
\end{abstract}

Keywords: marital assets, prenuptial agreement, divorce, the right to marital assets, spouses.

\section{Introduction}

The marital assets and prenuptial agreement are two institutes of family law that are seen initially seen in the Family Code in a law implemented in 2003.

Both Family Codes issued earlier than 1966 and 1982 other than the legal property do not provide for any other type of assets. The main feature of this type of regime is the minimization of the assets independence of the spouses due to the restriction of their freedom of their prenuptial contract.

But social and economic changes that occurred in the 90s in Albania not only changed the economic and political system, but also the Albanian families and relationships. Despite the fact that even today after 26 years of changes, the idea that the spouses should not be dependent on one another but should contribute to the family assets still has not changed.

A prenuptial agreement does not necessarily mean that being married is short or is going to end, but puts both spouses on an equal situation and free to choose how to manage their wealth.

Every social and economic relation is always evolving and the matrimonial assets are constantly changing. This is best illustrated by the 2003 Family Code which is based on the family Codes of two developed countries, France and Italy.

But although the law and especially the Family Code provide legal marital assets, divided assets and prenuptial agreement, it is still not implied in Albanian marriages. This means that the courts often encounter the problem of dividing the marital assets in divorce cases and the fact that the most difficult issue is how to divide these assets than the divorce itself.

The biggest problems arise in cases of dividing the marital assets when one spouse has been unemployed during the marriage and this spouse risks to have nothing after the divorce despite having brought other benefits to families such as child care, taking care of the house etc.

This study will focus on the types of matrimonial assets and how they are applied in Albania after the 90s and the legal framework about these marital assets.

This paper will not analyze the Albanian legislation on this institute but will compare this legislation with previous legislations, in order to show the development of this institute from its beginning, from the 1929' Civil Code, up to the present day. 


\section{The Goal and the Objectives of the Study}

The aim of this study is to evaluate the reasons why this institute is not implemented in our country even though the law foresees it, and to give an evolution panorama this legislation has gone through in this direction.

The main objective:

To argument why the divided marital assets do not have the important place it should have in the life of Albanian society after 1990'.

\section{The Questions of the Study and the Methodology}

The question of this study is:

- Why the regime in collaboration is more important in Albanian marriages?

- Why the prenuptial agreement has not found its area of implementation in Albanian society?

- What are the difficulties that the Albanian courts encounter in the division of the marital assets?

This study has a qualitative approach, as we will legally analyze and compare the evolution of the institution in Albanian society and the Family law.

\section{Describing, Analyzing and Interpreting the Data}

The universal declaration of the human rights determines that "Family is the basic and natural unit of the society." Starting form this definition, we may say that putting family in this particular law aspect as the Family Code is of great importance in social relations.

When a new family is created, it is important to determine the marital assets, which the future spouses will have during their life together. The marital assets are seen since the begining of the human society and the family. Even in the Canun of Leke Dukagjini, even though wives did not have equal rights as the husband, if the couple divorced, the assets were divided too, in favor of the husband.

The first time that such a law on marital assest is seen was on the Civil Code of 1929, or said differently the Civil Code of King Zog. According to this law the couple should sign a contract at the notary as a public act, before the marriage took place. Even though this was very modern for the time being, influenced by the French Code, it did not treat any assets in favor of the woman, excluding the cases of the assets that came from the death of the husband. In 1948 the parliament approved the law number nr.601 dated 18.05.1948, "On the marriage". This law regulated the way the assets were divided and their administration. According to this law, the assets of each spouse before marriage remained theirs, but the assets created during the marriage was under both ownership. In case the spouses asked for the separation of their assets, thay had to go to court, which in return divided the assets based on the contribute each spouse had given.

Marital assets regulations was arranged later by the Decree nr.2083 dt.06.08.1955 "On ownership" which in particular provided joint ownership between spouses. According to this decree the wealth acquired through work during marriage belongs to both of the spouses overall, except the assets that each spouse brought from their family of origin. Liabilities that each spouse had before marriage and those of each spouse taken to their own interests the other spouse was not responsible. Also, under this decree, the legal transactions done from each of the spouses for the joined things, were valid, despite the fact that they could be carried out without consent of the other spouse.

The inovation of this decree was that for the first time was recognized the division of joint assets of the spouses during the marriage when there was reasonable cause and not just in cases of divorce.

On 23.06.1965 the Family Code was approved, in the law Nr.4020, which started to implement on 01.01.1966 and legalized the regulation of matrimonial assets. According to this code the property which was developed by working during marriage was joined property and any contrary agreement would be invalid. In these circumstances it can be said that if there was a prenuptial agreement from one of the spouses, stating that one of them waives the right of ownership on the assets doen by joined working during the marriage would be void contract.

The Family Code was approved in 06.29.1982 with the Law nr.6599, but the assets regulations continued to act based on the Civil Code of 1982. The inovation of this Code in relation to the marital assets was recognition of equality in having joined property, and expanded the circle of items which consisted of joint ownership of spouses after marriage. Although this code was innovative, the problem of cash deposits in the bank by one spouse remained unsolved. This problem would be resolved by Article 86 of the Civil Code according to which the spouse who did not deposit did not have any rights on savings deposits made by the other spouse because it was not a contracting party to the relationship 
of the established liability.

In cases of divorce, separation of the deposit would be made by the spouses themselves or by the court. According to this Code joined property was what each spouse inherited or was given by by any other legal source.

Changes in the society of the 90s in Albania impacted significantly on property relations between spouses. Up until the recent years the marital assets consisted of household items, personal items and income from work. With the legalization of private property on the "Main Constitutional Provisions" of the law number 7491 dated on 29.04.1991 every citizen had the opportunity to create or buy property or restitute the properties taken by the communist regime through law 7689 dated on 15.04.1993 " for the Restitution and Compensation of Property" so the property of the spouses got bigger. All these changes needed a better regulaiton for the marital assets. In 2003 the govenment approved the New Family Code which was mainly based on marital assets provided in the Codes of French and Italian states. The changed conditions made it possible to implement the contract freedom of the spouses. The right of the marital assest provides:

A) The conditions and limitations where the marital assets are available.

B) The part of the assets pertaining the liabilities

Seen in this aspect the marital assets have to do with the wealth issues related to family life.

The inovation of the 2003 Code is the provision of the marital assests. In the article 66 of this code is stated that: The marital assets of spouses is regulated by law in the absence of a special agreement, where both spouses foresee the agreement they deserve, which should not contrast the disposals of this Code and legislation".

According to this Code the marital assets are:

1. Joined marital assets

2. Prenuptial agreement

3. The divided assets

The joined marital wealth or the legal union foreseen in the $73^{\text {rd }}$ article of the Code, is stated that: "The marital assets of the legal union is implemented when the spouses do not have any prenuptial agreements made". This regime is the most difficult one in the divorce cases. As the divorce causes many consequences, many of the western countries have accepted divorce very late. Italy made the divorce legal only in 1970, Spain in 1982, Ireland still does not accept the right to divorce in its legislation.

If the spouses do not choose one of the ways the Code determines, automatically the marital assets will be administered in the form of joined assets. This means that the wealth made during the marriage will be divided equally to both spouses in case of a divorce. The wages, the financial contribute or other means of one spouse might be bigger, this does not play a role in the division. So, even in the cases when one of the spouses has not worked even a day in their life, still the wealth obtained during the marriage will be equally divided.

The inovation of this Code is the provision of hte prenuptial agreement and the regime of divided assets. The prenuptial agreement is a new concept of the Code approved in 2003, and is a judicial act through which the future spouses decide for the marital assets for the time the marriege will last. In this contract they decide what wealth will be joined and what will be individual. The contract is developed by a notery and not only does it serve a evedence in case of a divorce, but also for the fact of marriage validity. It aims to decie the future economic status of the family, it can decide conditions that are not provided in the Code but not contrary to the Code.

When a prenuptial agreement is developed both spouses should be fully exact what they ask for, provided in article 69. The contract may change as long as the marriage has not happened, in contrary the spouses might change it based on article 72 of the Code which states that:

"spouses may agree in the interes of the family to change the agreement partially or totally only after two years of its implementation. In this case it would be done in the same way as the initial contract......".

But the prenuptial agreements still does not have the right place in Albanian family for some reasons:

1. Firstly, albanians still have the old mentality and still respect the traditional way of marriage, which makes it very difficult to have a prenuptial agreement.

2. Secondly, albanians are not that wealthy to think that in the first moment with the marriage comes the division of the wealth. Most often they only have a house and work salaries.

Although the marriage contract is a new thing, couples in most cases overlook the reasons mentioned above. When the judge decides, he announces the biggest decision of your life from now on, as you will turn your single life, and the troubles have started. It is not at all surprising that the Albanian couples, when separated by a court, start arguing for 
such wealth. Cases are not rare and it is because the former spouses are not satisfied by the separation of property. Men claim to have put the wealth themselves and that their ex-wives did not contribute, since most of them are unemployed or homemakers.

"Hiding" the assets is mainly made by husbands, who, without starting the divorce separation of the assets, give these assets to any of his relatives or not declare it at all, as family property. Above all, the separation of property of spouses after divorce is not an easy process, which, for the sake of truth, in terms of the market economy is the most challenging, the most serious and that leaves the worst consequences for all former members of a divorced family, even their heirs. Marriage contract is a necessity to be calm in any case of the separation of marital property. If there is not such a contract before marriage and before a public notary, who has a legal obligation to bring this contract to the Office of Civil Status, making it an integral part of the act of concluding a marriage, husbands are presumed to have chosen legal regime of joined assets. This presumption means that, if a man has received a loan or has a liability to third parties, his wife has the obligation to third parties also.

In the world, especially in the Western countries, dominates the regime of separated marital assets. Each spouse has its own his wealth, and increases or reduces it. Given the principle of "every man for himself", any spouse uses its wealth for individual obligations, for the debts or various other loans.

Such a regime makes it possible to divide the assets between the spouses even when they are still married. But when such a contract does not exist, without the announcement of the divorce, their joined assets cannot be divided. With the new family Code in case of an absence of a prenuptial agreement, the marital assets are equality divided. If the former spouses still live in the same apartment, this place is divided in half, but when they live in separate houses, they should pay to the respective one the corresponding price according to the market value. In this case, the law is not in favor of the parent who takes care of the children, but favors the "woman" who raises them to profit a food allowance, which the father has to pay monthly. The new Family Code follows the line of equality, without favoring the wife, differently from the code in other countries such as Germany, France, and England which give more marital assets to the wife or the parent who raises the children.

\section{Conclusions}

After an analyses of the law basics of the marital assets in Albania we can say that even after so many years, even though the family relations have changed enormously, the new families and the young couples have the tendency not to have a prenuptial agreement, as it is perceived like a step toward the divorce.

In order for the young couples to have a quiet and correct marriage which fulfills their needs it is necessary for each of them to have separate assets. The difficulties that are seen in the development of a prenuptial agreement come as a result of:

A) An underdeveloped mentality of the parents of both spouses, who think that this agreement is an unfortunate step toward the development of marriage based on a contract.

B) Family assets are very scarce in Albania, where most of the part the spouses may only have a inherited home from their parents.

C) Most of the Albanian women are unemployed and have no assets, so they are not interested in a prenuptial agreement.

\section{Recommendations}

To create strong relationships and healthy families is necessary to have suitable marital asset collaboration in case of a divorce.

To inform the youth who want to create a new family, on designing a prenuptial agreement, because in most cases young people do not have a clear idea what does it consist of and what they benefit.

To have more information about innovations of the Family Code which can be obtained from the Civil Registry Office where the marriage would be taking place.

To have a precise definition of marital assets and in particular the administration of marital property as a necessity to create a strong and healthy family, to precisely define the method of administration of marital property which brings in itself a coordination of future family. 


\section{References}

The main Constitutional issues

Civil Code 1929

Law nr.601 dt.18.05.1948 "For the marriage"

Article nr.2083 dt.06.08.1955 " For the Property"

Family Code 1966

Family Code 1982

Family Code 2003

The Universal Declaration of the Human Rights

Law Nr.10428 dt.02/06/2011 " For the international private right"

Mandro.A et al. "The family Right" Tirane 2006

Zaka T. "The marital assets, Albanian jurisprudence, and some comparing systems" The library of the Justice Faculty Tirane Begeja K. "The family Right in the Republic of Albania" Tirane 1984

Bonilini G. "Commentary I of the family right " Milano 2004 (translation of the non public Justice Faculty "Luarasi" Tirane

Legal studio wordpress.com "The marital assets according to the marriage"

Albanian law diary blogspot.com "How to separate the assets in case of a divorce"

www.doctoratura unitir.edu.al 